\title{
Islamic Psychology: Expanding Beyond the Clinic
}

\author{
Carrie York Al-Karam*
}

\section{Introduction}

As a modern field of inquiry, Islamic psychology (IP) has been emerging since roughly the 1970s. However, it has only noticeably accelerated into a recognizable "thing" over the past six or seven years, although what we today call psychology is by no means new to the Islamic intellectual tradition. In its modern expression, IP has been defined and conceptualized in a variety of ways, but is primarily a domain that seeks to develop theoretical and applied frameworks of psychology rooted in Islam. The field is still relatively small, both in terms of individuals involved as well as foci of scholarship. Many of us are psychologists or related mental health professionals (psychiatrists, counselors etc.), and much of the work focuses on clinical and mental health aspects such as models of the self/soul and spiritually integrated psychotherapy.

Given that the primary scope and readership of the Journal of Islamic Faith and Practice is not related to psychology, the purpose of this article, therefore, is to present IP to a new audience and to examine ways to grow the field, which includes expanding scholarship "beyond the clinic" as well as inviting colleagues in other domains, such as religious/Islamic studies, philosophy, history, chaplaincy, the arts, and beyond to contribute. Also, to bring the discussion within the purview of cross-cultural competency, a brief discussion of IP within an American context will be given, as well as recommendations for ways forward. This field review will be from the perspective of a Muslim psychologist actively involved in IP's development.

\section{What is Islamic Psychology? Its Emergence and Current Conceptualizations} IP has emerged in many scholarly contexts (for a description of some of this landscape, see Introduction in York Al-Karam, 2018a). Of particular relevance to our discussion here is the Islamization of Knowledge (IOK) movement, which has been primarily about how Muslims can contribute to the knowledge economy

\footnotetext{
* Carrie York Al-Karam is president of the Alkaram Institute, a nonprofit research and educational institution dedicated to advancing Islamic psychology to benefit society and improve lives. The institution conducts research, publishes scholarly works, and offers educational programs.
} 
from within their own worldview. Without digressing into a discussion of this movement specifically, as it relates to the field of psychology, most would agree that it was Malik Badri (b. 1932), a Sudanese psychologist now nearly 90 years old, who began to call for its Islamization as early as the 1960s.

In his landmark publication The Dilemma of Muslim Psychologists (1979), as well as his later publications (for example, see The Islamization of Psychology: Its Why, Its What, Its How, and Its Who, 2009), he highlighted a number of issues related to this process. According to him, Islamization was only needed in the areas of psychology "influenced by Western secularism and its ungodly worldview and its deviant conceptions about the nature of man" (p. 10). The domain of what many now refer to as Islamic psychology includes scholarship in areas of psychology that Badri said needed to be Islamized, some of which are highlighted below; however, it also includes other types of inquiry. Without repeating too much of what has been written previously (York Al-Karam, 2018a; 2018b), consider the following:

- Some scholarship focuses on the "nature of man" (ontology). This work explores concepts such as fitra, qalb, nafs, rüh, and 'aql, to name a few. Important publications in the psychological literature in this area include Mohammed (1995, 2009), Haque and Mohamed (2009), Haque and Keshavarzi (2013), Keshavarzi and Khan (2018), Keshavarzi, Khan, Ali, and Awaad (2020), Rothman (2018), and Rothman and Coyle (2018, 2020).

- Some scholarship is on spiritually integrated psychotherapy, an approach that integrates Islamic teachings, principles, philosophies, and/or interventions with Western therapeutic approaches (York Al-Karam, 2018a, p. 3). Examples of Islamically integrated psychotherapy include the use of Quranic stories in family therapy (Malik, 2018), an Islamic model of the self in counseling (Rothman, 2018; Rothman \& Coyle, 2018, 2020; Keshavarzi and Khan, 2018), or using Prophet Mohammed as a psychospiritual exemplar in cognitive therapy (Lodi, 2018). There are also a number of noteworthy books on this topic by Rassool (2016), Khalily (2018), York Al-Karam (2018a), and, most recently, Keshavarzi, Khan, Ali, and Awaad (2020).

- Some think the work of early Muslim scholars such al-Kindi, al-Razi, alBalkhi, al-Ghazali, and others is IP, as they wrote about topics that today are considered "psychology." See Haque (2004), Awaad and Ali (2014, 2015), and Awaad, Elsayed, Ali, and Abid (2020) for more on this.

- Some suggest that IP is essentially tașawwuf or tazkiyat al-nafs, arguing that these are Islam's version of psychology/psychotherapy (York AlKaram, 2018a, 2018b). 
- Some suggest that IP is about spiritual diseases of the heart like anger, hatred, or arrogance - that they are Islam's version of "psychopathology" (York Al-Karam, 2018a, 2018b).

- Some think IP is psychology about Muslims, by Muslims, and/or for Muslims.

- Some think it is an "Islam and Psychology" domain that mainly compares/contrasts or filters various psychology ideas through an Islamic lens (Kaplick \& Skinner, 2017; Abu Raiya, 2012).

- Some use other names such as Quranic psychology, Islamic moral psychology (for example, see Bakhtiar, 2019), or Islam-based psychology (Fatemi, 2020). Related to this, some work that could be considered IP might call itself something else completely and be positioned in other scholarly contexts.

- Some confuse it with the field of Muslim mental health, which explores the mental health needs of Muslims (York Al-Karam, 2018a; 2018b).

In addition to these specific types of scholarship or conceptual understandings, some theoretical work has also been done on the field. For example, York AlKaram (2018b) proposed the Tawheedic Paradigm as a conceptual model to both define and unite the field. This paradigm generates the following definition: IP is an "interdisciplinary science where psychology subdisciplines and/or related disciplines engage scientifically about a particular topic and at a particular level with various Islamic sects, sources, sciences, and/or schools of thought using a variety of methodological tools" (p. 101).

The model highlights that neither psychology nor Islam are one thing; rather, they are broad umbrella terms that encompass many sub-"things." And it is those sub-"things" that engage with each other to produce bits of knowledge that advance the field. This definition naturally points to and accommodates the great diversity of Islam/Muslims, and therefore shows how diverse IP can be. Other work includes exploring collaborative research methods (Alias \& Noor, 2009; Kaplick, Chaudhary, Hasan, Yusuf, \& Keshavarzi, 2019) or other matters related to the field (Sahin, 2013; Long, 2019).

\section{Expanding IP}

Although much good work has been done, much of it has been clinical. Clinical psychology is perhaps the largest and most popular of psychology's subfields, as it focuses on psychopathology and treatment. Despite its great relevance and importance to us all, psychology has many other areas.

For example, social psychology is about understanding human behavior in groups and includes topics like prejudice, altruism, social conformity, obedience, aggression, and groupthink. Industrial/Organizational psychology explores job 
performance, employee characteristics, recruitment processes, training needs, employee motivation, and job satisfaction. Positive psychology explores human flourishing and includes topics like virtues and character strengths. Educational psychology explores teaching, instructional design, and curriculum development. School psychology deals with children in schools, the learning process, and classroom and school environments.

Although a few publications on some of psychology's other areas do exist (for example, see Chalebi, 2001; Ali \& Keshavarzi, 2016, 2017. For forensic psychology and for a few other non-clinical areas, see chapters in Noor, 2009), these fields are still mostly unexplored.

Moreover, all of psychology's subfields are built upon units of knowledge, including learning, memory, perception, motivation, emotion, intelligence, and human development. Psychologists then apply this knowledge to understanding a whole host of other topics like parenting, stress, abuse, trauma, human rights, disability, ethics, shyness, adoption, and violence - the list is endless! So the questions then become what Islam has to say about these topics and how that is in conversation with what modern psychology says about them.

We also need IP scholarship in the area of tazkiyaltasawwuf. Staple topics for theologians, this area includes topics like spiritual diseases of the heart such as anger and jealousy, behavioral "disorders" like lying or gossip, spiritual practices like murāqaba and muhāsaba, or developing virtues like patience, gratitude, and overall good character.

Other ways the field could grow are in areas that are indeed "psychology" but are often not necessarily thought of as such. For example, urban and architectural design, poetry, music, and art. In other words, what do Islam and Muslim thought have to say about these and how is that in conversation with psychological perspectives of the day on them?

In addition to expanding scholarship, growing the field also requires the involvement of more people. In terms of psychologists, we need more Muslim psychologists in general, regardless of their scholarly interests. But we also need more of them in IP. Perhaps even more importantly, we need scholars from religious/Islamic studies, philosophy, history, and beyond to contribute. Surely, they are already working on many of the topics with which IP is concerned. The problem is that we do not talk to each other, largely because the Western academy makes a demarcation between sciences like psychology and the humanities like religious studies or philosophy, despite the fact that all of these domains are inherently interdisciplinary. This demarcation is foreign to the Islamic intellectual tradition. Thus, as part of growing the IP field, we must bridge this scholarly divide.

I would also argue that we need to think about how the science of IP might have relevance to other applied domains like pastoral care and chaplaincy, especially given the burgeoning field of Islamic chaplaincy within the North American 
context over the past years and since the establishment of programs at institutions like Bayan Claremont and Hartford Seminary as well as organizations like the Association of Muslim Chaplains.

\section{Islamic Psychology in a non-Muslim Context}

In addition to examining how IP can grow, at least two questions need to be addressed. First, what relevance does IP have vis-à-vis mainstream psychology and, second, what relevance does IP have to non-Muslims?

In order to answer the first question, one must understand psychology today. Although the discipline promotes itself as being a (secular) science, having eschewed itself from its earlier religious and philosophical roots, in reality this is not entirely true because there are pockets within the field that explore beyond "science." For example, the American Psychological Association (APA), the largest professional psychology association in the world with some 120,000 members, has divisions, books, and journals that focus on these areas.

In Division 36, the Society for the Psychology of Religion and Spirituality, psychologists study things like virtue and character development (Schnitker), constructs like humility and grace (Hill), religious struggles (Exline), spiritual development (King), and the robust area of spiritually integrated psychotherapy (Pargament, 2007; Richards \& Bergin, 2001, 2003; Plante, 2009; York Al-Karam, 2018; Rothman, 2018, 2020; Keshavarzi \& Khan, 2018, 2020). The largest study to date on this topic, Bringing Spiritually Integrated Psychotherapies into the Healthcare Mainstream: A Big-Data Project (Bridges, 2020) was supported with a \$3.5 million dollar grant from the John Templeton Foundation and had over 30,000 responses from clients and 23,000 responses from clinicians (Bridges, 2020). Moreover, one of APA's peer-reviewed journals, Spirituality in Clinical Practice, recently published a paper on IP that presents an Islamic theoretical orientation to psychotherapy based on an explicitly Islamic notion of ontology (Rothman, 2020). One can also consider work on religious psychologies (for example, see Sisemore \& Knapp, 2020).

Without digressing too much (one could write a whole book on this topic!), the point is this: Despite many remaining challenges, psychology in the 21 st century has very much been about "diversity and inclusion." We would therefore be remiss to ignore this, as well as the large volume of scholarship that has pushed the boundaries of psychology, whether it be in the areas of religion, philosophy, or even related to the decolonization of psychology, some of which can be seen in the development of Native American, Latino, Asian, Black, and other racial, ethnic, or minority psychologies (for example, see Division 45 - the Society for the Psychological Study of Culture, Ethnicity, and Race. For philosophy, see Division 24 - the Society for Theoretical and Philosophical Psychology). 
That is not to say that anti-religion sentiments in psychology have disappeared, because they have not. There are many psychology departments and psychologists who are staunchly secular and even anti-religion. There are also psychologists who are oblivious to the areas of psychology scholarship that push its boundaries into the realms of religion, philosophy, and the like, even though it has become a rather robust area by now. This will always be the case, because secularists/atheists will always exist and one cannot always know everything about one's field, especially when it is as vast as psychology.

However, Muslims need to understand the nuance of this landscape not only as potential psychology consumers, but also because it helps one understand IP's position within psychology today - that it is not some niche field, but rather part and parcel of the broader mainstream. It is also worth mentioning that IP should not be a domain that is exclusive to Muslim scholars, even though many of us will be Muslim.

In terms of IP's relevance to non-Muslims, we must first acknowledge that according to Islamic teachings, God sent Islam to everyone. Thus, we should think about IP in that way as well. Relatedly, literature has explored Islamic therapies on non-Muslims, with some positive results (for example, see York AlKaram, 2015). In short, each IP scholar must ask the question as to what potential relevance his or her work might have to anyone - what its "generalizability" might be. That said, not everything is generalizable. All things have limitations just like secular psychology - and there is nothing wrong with that. But we still need to ask the question, and there most likely will always be some kernel of benefit even for those for whom it might be less relevant.

\section{Moving Forward}

This brief article has presented a few suggestions as to how to expand IP "beyond the clinic," as well as how this field might fit within an American context. In terms of moving forward, a number of other things can also be done.

First, people already working in higher education (especially professors) can ask how their departments could contribute to the IP field. For example, does their department have faculty interested in IP? If not, what could they do to change that? Do they have students who are interested in IP topics? Does the department have the capacity to offer a talk, symposium, conference, or course on IP? And if it does, could it be co-hosted or cross-listed with other departments, thereby being an opportunity to collaborate with departments that do not usually talk to each other?

Relatedly, Muslim educational institutions in the United States like Zaytuna College, Bayan Claremont, the American Islamic College, as well as seminaries like the Islamic Seminary of America or other institutions that focus on the Islamic sciences and spirituality, could ask what interests and capacities 
they have. Classical Muslim scholars like al-Balkhi and others who wrote on topics that we today call psychology were first and foremost theologians, and certainly theologians are experts on many of IP's topics. Perhaps those who are first trained as theologians could consider going into psychology as a profession.

Second, those interested in the field can take advantage of existing infrastructure. For example, the Alkaram Institute, the only academic institution in the US dedicated to IP and whose vision is to become the first Muslim graduate school of psychology in the US, has a research fellowship that was designed to expand IP scholarship by providing support to MA and PhD students in universities anywhere in the world doing their theses or dissertations on IP, but whose departments do not have faculty with the requisite expertise. The initiative also supports (non-student) professionals who would like to develop an area of IP scholarship but need support in doing so. Related to this, completed scholarship can then be presented at conferences sponsored by the International Association of Islamic Psychology (IAIP) and published in its Journal of Islamic Psychology (which will release its first volume in the near future).

Third, the APA and the American Academy of Religion (AAR) could start talking to each other. The APA has divisions that explore religion, and the AAR has program units that explore psychology - our subjects and topics of inquiry are not mutually exclusive! It is not entirely clear how this might happen, but it would certainly be historic and also quite provocative if it did. Could Muslims, via the field of IP, facilitate a change in this regard?

There are many challenges to developing a "new" field of inquiry. As it relates specifically to IP and within an American context, some of these challenges are the academy's disjointed nature, Islamic perspectives being in the minority, and also a general lack of knowledge about the field's existence and goals.

That said, I believe we are in a zeitgeist of diversity and inclusion. Given this, it is a good time to be a Muslim in the United States and in psychology. People are calling for Muslim voices, and Muslims are speaking up and contributing. What is most needed now are individuals from all fields of inquiry who are creative, confident, and authentic in who they are and what they have to offer to come together and collectively advance Islamic psychology's noble mission, which is "to benefit society and improve lives" - for everyone, everywhere.

\section{References}

Abu-Raiya, H. (2012). Towards a systematic Qur'anic theory of personality. Mental Health, Religion \& Culture, 15(3), 217-233.

Ali, B. \& Keshavarzi, H. (2017). Forensic psychiatry. In Oxford Islamic Studies Online. Oxford Islamic Studies. http://www.oxfordislamicstudies.com/ article/opr/t343/e0250 
Alias, A. \& Noor, N. (2009). An integrated methodology for the social sciences. In N. Noor (Ed.), Psychology from an Islamic perspective. Malaysia: IIUM Press.

Awaad, R., \& Ali, S. (2014). Obsessional disorders in al-Balkhi's 9th century treatise: Sustenance of the body and soul. Journal of Affective Disorders, 180, 185-189. doi:10.1016/j.jad.2015.03.003

Awaad, R., \& Ali, S. (2015). A modern conceptualization of phobia in al-Balkhi's 9th century treatise: Sustenance of the body and soul. Journal of Anxiety Disorders, 37, 89-93. doi:10.1016/j.janxdis.2015.11.003:

Awaad, R., Elsayed, D., Ali, S., and Abid, A. (2020). Islamic psychology: A portrait of its historical origins and contributions. In H. Keshavarzi, F. Khan, S. Ali, \& R. Awaad (Eds.), Applying Islamic principles to clinical mental health care. NY: Routledge.

Badri, M. (1979). The dilemma of Muslim psychologists. London: MWH London.

Badri, M. (2009). "The Islamization of psychology: Its "why", its "what", its "how" and its "who." In N. Noor (Ed.). Psychology from an Islamic perspective (pp. 13-41). Malaysia: IIUM Press. First delivered as a keynote speech circa 2002.

Bakhtiar, L. (2019). Quranic psychology of the self: A textbook on Islamic moral psychology. Chicago: Kazi Publications.

Bridges Consortium Research Project website: http://www.bridgesconsortium.net. Data reference is an internal report not yet published.

Chaleby, K. (2001). Forensic psychiatry in Islamic jurisprudence. Herndon, VA: The International Institute of Islamic Thought.

Exline, J. (2020). For a full list of Julie Exline's publications on religious struggles, see https://artscimedia.case.edu/wp-content/uploads/2013/07/ 02151601/Exline- CV-2019.pdf

Fatemi, S. (2020). An overview of an Islam-based psychology. In T. Sisemore \& J. Knabb (Eds.), The psychology of world religions and spiritualities. Pennsylvania: Templeton Press.

Haque, A. (2004). Psychology from Islamic perspective: Contributions of early Muslim scholars and challenges to contemporary Muslim psychologists. Journal of Religion and Health, 43(4), 357-377. doi:10.1007/s10943-0044302-z

Haque, A., \& Mohamed, Y. (2009). Psychology of personality: Islamic perspectives. Singapore: Cengage Learning Asia.

Haque, A. \& Keshavarzi, H. (2013). Outlining a psychotherapy model for enhancing Muslim mental health within an Islamic context. The International Journal for the Psychology of Religion, 23, 230-249. 
Haque, A. (2018). A brief overview of Islamic psychology. In L. Lambert \& N. Pasha-Zaidi (Eds.), An introduction to psychology for the Middle East (and beyond). United Kingdom: Cambridge Scholars Publishing.

Hill, P. (2020). See publications by Prof. Peter Hill. https://cct.biola.edu/people/ peter-c-hill/

Kaplick, P. M., \& Skinner, R. (2017). The evolving Islam and psychology movement. European Psychologist, 22(3), 198-204. https://doi.org/10.1027/ 1016-9040/a000297

Kaplick, P., Chaudhary, Y., Hasan, A., Yusuf, A., \& Keshavarzi, H. (2019). An interdisciplinary framework for Islamic cognitive theories. Journal of Religion and Science, 54(1), 66-85.

Keshavarzi, H. \& Khan, F. (2018). Outlining a case illustration of traditional Islamically integrated psychotherapy. In C. York Al-Karam (Ed.), Islamically integrated psychotherapy: Uniting faith and professional practice. Pennsylvania: Templeton Press.

Keshavarzi, H., Khan, F., Ali, B., \& Awaad, R. (Eds.). (2020). Applying Islamic principles to clinical mental health care: Introducing traditional Islamically integrated psychotherapy. New York: Routledge.

Khalily, M. (2018). Taking faith seriously in therapeutic psychology. Islamabad: The Iqbal International Institute for Research and Dialogue.

King, P. (2020). For a list of some of Prof. King's publications, see https://www. fuller.edu/academics/school-of-psychology/travis-research-institute/thrivelab-king-lab/

Lodi, F. (2018). The HEART method: Healthy emotions anchored in Rasool Allah's teachings: Cognitive therapy using Prophet Muhammad as a psychospiritual exemplar. In C. York Al-Karam (Ed.), Islamically integrated psychotherapy: Uniting faith and professional practice. Pennsylvania: Templeton Press.

Long, W. (2019). Indigenous psychology: Going nowhere slowly? Journal of Theoretical and Philosophical Psychology, 39(2), 115-119.

Malik, R. (2018). Family therapy and the use of Quranic stories. In C. York AlKaram (Ed.), Islamically integrated psychotherapy: Uniting faith and professional practice. Pennsylvania: Templeton Press.

Mohamed, Y. (1995). Fitrah and its bearing on the principles of psychology. The American Journal of Islamic Social Sciences, 12(1), 1-18.

Mohamed, Y. (2009). Human Natural Disposition (Fitrah). In A. Haque \& Y. Mohamed (Eds.), Psychology of personality: Islamic perspectives (pp. 318). Singapore: Cengage Learning Asia.

Noor, N. (Ed.). (2009) Psychology from an Islamic perspective. Malaysia: IIUM Press. 
Pargament, K. (2007). Spiritually integrated psychotherapy: Understanding and addressing the sacred. New York: Guilford Press.

Plante, T. (2009). Spiritual practices in psychotherapy: Thirteen tools for enhancing psychological health. Washington, DC: The American Psychological Association.

Rassool, G. H. (2016). Islamic counseling: An introduction to theory and practice. United Kingdom: Routledge.

Richards, P. S., \& Bergin, A. (2000). Handbook of psychotherapy and religious diversity. Washington, DC: The American Psychological Association.

Richards, P. S., \& Bergin, A. (1997). A spiritual strategy for counseling and psychotherapy. Washington, DC: The American Psychological Association.

Rothman, A. (2018). An Islamic theoretical orientation to psychotherapy. In C. York Al-Karam (Ed.), Islamically integrated psychotherapy: Uniting faith and professional practice. Pennsylvania: Templeton Press.

Rothman, A. \& Coyle, A. (2018). Toward a framework for Islamic psychology and psychotherapy: An Islamic model of the soul. Journal of Religion and Health 57(50), 1731-1744. Springer

Rothman, A. (2020). Conceptualizing and Islamic psychotherapy: A grounded theory study. Spirituality in Clinical Practice. Heeps://doi.apa.org/ doiLanding? doi=10.1037\%2Fscp0000219

Sahin, A. (2013). Reflections on the possibility of an Islamic psychology. Archive for the Psychology of Religion, 35(3), 321-335.

Schnitker, S. (2020). For an introduction to this project, see https://www.baylor. edu/virtue-development/index.php?id=963954

Sisemore, T., \& Knabb, J. (Eds.). (2020). The psychology of world religions and spiritualities. Pennsylvania: Templeton Press.

York Al-Karam, C. (2015). Complementary and alternative treatments in psychology: An Islamic therapeutic modality. In C. York Al-Karam \& A. Haque (Eds.). Mental health and psychological practice in the United Arab Emirates. New York: Palgrave Macmillan.

York Al-Karam, C. (2018a). Islamically integrated psychotherapy: Uniting faith and professional practice. Pennsylvania: Templeton Press.

York Al-Karam, C. (2018b). Islamic psychology: Towards a $21^{\text {st }}$ century definition and conceptual framework. Journal of Islamic Ethics, 2(2018), pp. 97-109. Brill Publications.

York Al-Karam, C. (2018c). Approaches to the science of psychology (pp. 10 11) and Islamic perspective of mental illness (p. 287). In L. Lambert \& N. Pasha-Zaidi (Eds.), An introduction to psychology for the Middle East (and beyond) (p. x). Newcastle Upon Tyne, UK: Cambridge Scholars Publishing. 